OPEN ACCESS

Edited by:

Dietmar Zehn,

Swiss Vaccine Research Institute,

Switzerland

Reviewed by:

Sabine Hammer,

Vetmeduni Vienna, Austria

Alice Sijts,

Utrecht University, Netherlands

${ }^{*}$ Correspondence:

Hongyan Chen

hychen@hvriac.cn

Specialty section: This article was submitted to Antigen Presenting Cell Biology, a section of the journal

Frontiers in Immunology

Received: 29 December 2016 Accepted: 28 February 2017

Published: 15 March 2017

Citation:

Gao C, Quan J, Jiang X, Li C, LU X and Chen $H$ (2017) Swine Leukocyte Antigen Diversity in Canadian Specific

Pathogen-Free Yorkshire and Landrace Pigs.

Front. Immunol. 8:282.

doi: 10.3389/fimmu.2017.00282

\section{Swine Leukocyte Antigen Diversity in Canadian Specific Pathogen-Free Yorkshire and Landrace Pigs}

\author{
Caixia Gao, Jinqiang Quan, Xinjie Jiang, Changwen Li, Xiaoye Lu and Hongyan Chen* \\ Laboratory Animal and Comparative Medicine Team, State Key Laboratory of Veterinary Biotechnology, Harbin Veterinary \\ Research Institute, Chinese Academy of Agricultural Sciences (CAAS), Harbin, China
}

The highly polymorphic swine major histocompatibility complex (MHC), termed swine leukocyte antigen (SLA), is associated with different levels of immunologic responses to infectious diseases, vaccines, and transplantation. Pig breeds with known SLA haplotypes are important genetic resources for biomedical research. Canadian Yorkshire and Landrace pigs represent the current specific pathogen-free (SPF) breeding stock maintained in the isolation environment at the Harbin Veterinary Research Institute, Chinese Academy of Agricultural Sciences. In this study, we identified 61 alleles at five polymorphic SLA loci (SLA-1, SLA-2, SLA-3, DRB1, and DQB1) representing 17 class | haplotypes and 11 class || haplotypes using reverse transcription-polymerase chain reaction (RT-PCR) sequence-based typing and PCR-sequence specific primers methods in 367 Canadian SPF Yorkshire and Landrace pigs. The official designation of the alleles has been assigned by the SLA Nomenclature Committee of the International Society for Animal Genetics and released in updated Immuno Polymorphism Database-MHC SLA sequence database [Release 2.0.0.3 (2016-11-03)]. The submissions confirmed some unassigned alleles and standardized nomenclatures of many previously unconfirmed alleles in the GenBank database. Three class I haplotypes, Hp-37.0, 63.0, and 73.0, appeared to be novel and have not previously been reported in other pig populations. One crossover within the class I region and two between class I and class I| regions were observed, resulting in three new recombinant haplotypes. The presence of the duplicated SLA-1 locus was confirmed in three class I haplotypes Hp-28.0, $\mathrm{Hp}-35.0$, and Hp-63.0. Furthermore, we also analyzed the functional diversities of 19 identified frequent SLA class I molecules in this study and confirmed the existence of four supertypes using the MHCcluster method. These results will be useful for studying the adaptive immune response and immunological phenotypic differences in pigs, screening potential T-cell epitopes, and further developing the more effective vaccines.

Keywords: major histocompatibility complex, swine leukocyte antigen, diversity, specific pathogen-free, Yorkshire, Landrace

Abbreviations: MHC, major histocompatibility complex; SLA, swine leukocyte antigen; SPF, specific pathogen-free; RT-PCR, the reverse transcription polymerase chain reaction; SBT, sequence-based typing; PCR-SSP, PCR-sequence specific primers; IPD, the Immuno Polymorphism Database; ISAG, International Society for Animal Genetics. 


\section{INTRODUCTION}

Swine major histocompatibility complex (MHC), which codes for swine leukocyte antigen (SLA), has been mapped to pig chromosome 7 spanning the centromere. SLA genes are highly polymorphic comprising classical class I, II, and III genes (1). SLA class I and class II proteins are involved in the adaptive immune response through their respective presentations of endogenous and exogenous peptide antigens to circulating $\mathrm{T}$ lymphocytes (2). Class I molecules are recognized by cytotoxic T lymphocytes, which kill transformed cells and virally infected cells, thus preventing tumor cell replication or pathogen release. Class II molecules are recognized by helper T cells, which induce or permit immune responses, including the production of antibodies to extracellular pathogens. Class III molecules include many important immune-defense genes, such as the tumor necrosis factor gene families and components of the complement cascade (3). Among SLA class I and class II genes, SLA-1, SLA-2, SLA-3, $D R B 1$, and $D Q B 1$ are highly polymorphic. Up to now, 192 classical SLA class I alleles (69 SLA-1, 87 SLA-2, and $36 S L A-3$ ) and 145 polymorphic class II alleles (91 DRB1 and $54 D Q B 1$ ) have been designated by the SLA Nomenclature Committee of the International Society for Animal Genetics (ISAG) in the Immuno Polymorphism Database (IPD)-MHC SLA sequence database. ${ }^{1}$

Yorkshire and Landrace pigs are widely distributed in the world. When every country develops breeding according to their need, characteristics of natural populations are kept, and the certain special features are bred. These two breeds are the famous leading lean hogs around the world. There are few reports using them as experimental animals for veterinary and medical studies. However, pigs have an evolutionary resemblance to humans and share anatomical, physiological, immunological, metabolic, and nutritional similarities, making them promising organ donors for xenotransplantation. Additionally, because of their white fur, small genetic differentiation, stable genetic structure, and lack of major swine diseases as well as the corresponding antibodies, Canadian Yorkshire and Landrace pigs are more suitable as animal models for the study of virus infections and pathogenesis, host immunological responses, vaccine evaluation, and the identification of T-cell epitopes. However, the different allelic forms of the SLA complex have been confirmed to bind different classes of peptides, and the presence of unknown SLA types in pigs could thus potentially confound the results of such studies (4-6). SLA typing is therefore necessary to our understanding of SLA peptide antigen binding and presentation. Determining which SLA alleles are expressed by the animals is an essential initial step in identifying virally derived T-cell epitopes that play a role in generating protective $\mathrm{T}$ cell responses against infection in pigs. Following SLA typing, candidate peptide antigens can be screened by various techniques, such as cytotoxic lymphocyte peptide and cytokine stimulation, peptide MHC affinity and stability assays, flow cytometric analyses of T-cell populations specific for peptide MHC tetramers, and by the web resource ICES index ${ }^{2}(7-12)$.

${ }^{1}$ http://www.ebi.ac.uk/ipd/mhc/group/SLA, Release 2.0.0.3 (2016-11-03). ${ }^{2}$ http://sb.nhri.org.tw/ICES.
In this process, the identification of peptides binding to SLA alleles is a critical step. The MHCcluster method just provides an important tool for functionally clustering MHC molecules based on their predicted binding specificities (13).

In this study, we characterized the alleles of five polymorphic SLA loci (SLA-1, SLA-2, SLA-3, DRB1, and DQB1) identified in Canadian specific pathogen-free (SPF) Yorkshire and Landrace parental breeding pigs using sequence-based typing (SBT), followed by use of a rapid polymerase chain reaction sequencespecific primer (PCR-SSP) method for SLA typing and to assign alleles to haplotypes in the progeny. Following identification of the common SLA class I alleles in Yorkshire and Landrace pigs, we then used the MHCcluster method to compare the peptidebinding functions of their encoded proteins. The results of this study will help to develop Yorkshire and Landrace pigs with well-defined SLA as important and useful laboratory animals for investigating pathogenic and immunological mechanisms for various porcine pathogens, as well as for furthering our understanding of the structural and functional implications of SLA gene polymorphisms.

\section{MATERIALS AND METHODS}

\section{Animals}

Yorkshire and Landrace pigs in this study were imported from Canadian Genesus incorporated in 2014 and represent the current breeding stock maintained in the isolation environment at the Harbin Veterinary Research Institute of the Chinese Academy of Agricultural Sciences. All the pigs have been free of 12 major swine diseases as well as their corresponding antibodies, including foot and mouth disease, classical swine fever, porcine reproductive and respiratory syndrome, Japanese encephalitis, pseudorabies, transmissible gastroenteritis, Brucella, Bordetella bronchiseptica, Actinobacillus pleuropneumoniae, swine mycoplasmal pneumonia, swine influenza, and porcine epizootic diarrhea. Therefore, they are excellently suited as laboratory animals for biomedical research. In this study, blood samples were obtained from 37 parental breeding pigs, including 15 Yorkshire $\left(40^{\star}, 11\right.$ \%) and 22 Landrace $\left(60^{\star}, 169\right)$ pigs, for isolation of peripheral blood mononuclear cells. Ear tissues were collected from $330 \mathrm{~F} 1$ progeny pigs for DNA extraction, including 113 Yorkshire, 157 Landrace, and 60 crossbred Yorkshire and Landrace progeny pigs. The swine pedigree was showed in Table S1 in Supplementary Material. All sample collections were approved by the ethical review board of Harbin Veterinary Research Institute of the Chinese Academy of Agricultural Sciences and performed in accordance with animal ethics guidelines and approved protocols. The animal Ethics Committee approval number is Heilongjiang-SYXK-2006-032.

\section{Identification of SLA Alleles by SBT}

Five pairs of full-length locus-specific primers were used to amplify the complete coding sequences of five SLA loci (SLA-1, $S L A-2, S L A-3, D R B 1$, and $D Q B 1)$. The primers for SLA-2, SLA3, $D R B 1$, and $D Q B 1$ genes were as described by Ho et al. (14). The primers for the SLA-1 locus were redesigned as follows: SLA1-F (5'-CTC AGC TTC TCC CCA GAC CCC GAG GCT 
GAG GAT C-3') and SLA1-R (5'-GGA TTC TGG AAG GTT CTC AAT CCT TCC ATT TAT TTC CTC-3'). Extraction of total RNA from peripheral blood mononuclear cells, synthesis of cDNA, and reverse transcription-PCR amplification were carried out as described previously (15). All PCR products were purified, and nucleotide sequences were determined by direct and cloning sequencing. For direct sequencing, two internal sequencing primers, SLA1f (5'-GGC TTC TAC CCT AAG GAG A-3') and SLA1r (5'-GCC CAC TTC TGG AAG GT-3'), were used to determine the cDNA sequences of three class I genes (SLA-1, SLA-2, and SLA-3). All sequences were submitted to the GenBank database. Compared with the published SLA alleles in the IPD-MHC SLA sequence database, novel alleles as well as the corresponding haplotypes were assigned official names by the ISAG SLA Nomenclature Committee.

\section{SLA Genotyping by PCR-SSP}

A total of $330 \mathrm{~F} 1$ progeny of Canadian SPF Yorkshire and Landrace pigs were genotyped for their SLA class I (SLA-1, SLA-2, and $S L A-3)$ and class II (DRB1 and DQB1) alleles by PCR-SSP method using extracted DNA samples. These included 113 Yorkshire, 157 Landrace, and 60 crossbred Yorkshire and Landrace progeny. All animals were SLA-typed using the complete set of primers specific for the alleles at all five SLA loci and most of primers followed that by Ho et al. $(16,17)$ (Table S2 in Supplementary Material). The reaction volumes, cycling conditions, and interpretation of PCR amplification were performed as described previously (15). The ACTA 1 gene (porcine $\alpha$-actin) was used as a positive control, and a negative control without DNA was setup for each typing, to check for reagent contamination (lane 1).

\section{MHCcluster Analysis}

Comparative analysis of peptide-binding function was performed using the MHCcluster method $^{3}$ for in-house and identified frequent SLA class I alleles in this study. In brief, MHCcluster was used to cluster SLA molecules functionally based on their predicted binding specificity to 50,000 random natural 9 amino acid long peptides (13). This analysis predicts binding motifs for SLA class I molecules.

\section{RESULTS}

\section{SLA Diversity in Yorkshire and Landrace Pigs}

A total of 43 class I (16 SLA-1, 16 SLA-2, and 11 SLA-3) and 18 class II alleles (8DQB1 and $10 D R B 1)$ were identified at five SLA loci in 15 Yorkshire and 22 Landrace pigs by SBT (Table 1; Data Sheet $\mathrm{S} 1$ in Supplementary Material). All the nucleotide sequences and protein sequences have been submitted to the GenBank database under the accession numbers KU754544-KU754601 and KU953375-KU953377. Comparisons with other published

${ }^{3}$ http://www.cbs.dtu.dk/services/MHCcluster/. sequences in the IPD-MHC SLA sequence database indicated that three of the alleles were novel and the official allele names $S L A-3^{\star} 05: 03: 02, D R B 1^{\star} 06: 07$, and $D Q B 1^{\star} 02: 12$ were assigned by the ISAG SLA Nomenclature Committee. The official designation of alleles identified in this study confirmed some unassigned alleles and standardized nomenclatures of many previously unconfirmed alleles in the GenBank database (Table 2). The nucleotide sequences of four alleles identified in the 16 samples by SBT were identical to those with GenBank accession numbers KX056221, KT194212, and KT350995; AK351685; DQ992497, DQ992498, and DQ992499; and AK239592, respectively, without official allele names. Therefore, the four confirmed allelic sequences were designated as: $S L A-1^{\star} 07: 04$ (KU754554), SLA$1^{\star} 08: 11$ (KU754558), SLA-2*16:03 (KU754568), and SLA-2*10:06 (KU754570), respectively, by the Committee. Furthermore, $S L A-1^{\star} 08 \mathrm{pt} 13, S L A-1^{\star} 08 \mathrm{sk} 11, S L A-1^{\star} 11 \mathrm{jh} 02, S L A-2^{\star} \mathrm{w} 09 \mathrm{pt} 22$, $S L A-2^{\star} 10 \mathrm{es} 21, S L A-2^{\star} 10 \mathrm{sk} 21, S L A-3^{\star} 03 \mathrm{pt} 31$, and $S L A-3^{\star}$ hb06 alleles had previously been identified in other pig breeds and some cell lines, e.g., Korean native pigs, Danish swine, Landrace pigs, cell lines "ESK-4, PT-K75, SK-RST," and so on (18-21). These alleles were therefore assigned the following permanent names by the SLA Nomenclature Committee: $S L A-1^{\star} 08: 07$ (KU953375), SLA- $1^{\star} 08: 08$ (KU754548), SLA-1*11:03 (KU754550), SLA$2^{\star}$ 09:03 (KU953376), SLA-2*10:04 (KU754565), SLA-2*10:05 (KU754566), SLA-3*03:06 (KU953377), and SLA-3*04:04 (KU754583), respectively. The nucleotide sequences of $S L A$ $1^{\star}$ rh03 (AF074427), SLA-2*05rh03 (AF074428), DRB1*06sL47 (L08847), DQB1*0203 (AB012093, AF113970), and DQB1*0204 (L08844, EU039916) had previously been submitted to the IPDMHC database and were identical to the partial coding sequences (exons 2 and 3 of SLA class I genes and exon 2 of class II genes) that we identified in SPF Yorkshire and Landrace pigs. Therefore, the official allele names were assigned as follows by the committee, according to the SLA nomenclature rules (22-24): SLA$1^{\star}$ 07:03 (KU754555), SLA-2*05:05 (KU754569), DRB1*06:07 (KU754601), DQB1*02:03 (KU754591), and $D Q B 1^{\star} 02: 12$ (KU754590), respectively. The other official allele designations assigned by the ISAG SLA Nomenclature Committee are shown in Table S2 in Supplementary Material. IPD-MHC database has been updated in 2016 and the confirmed alleles in this study have been released in database [Release 2.0.0.3 (2016-11-03)]. In addition, more than two $S L A-1$ alleles each were detected in seven of the 37 SBT-typed pigs, indicating the presence of a duplicated SLA-1 locus in multiple SLA haplotypes in Canadian SPF Yorkshire and Landrace pigs. Notably, the $S L A-1^{\star}$ 09:01 allele was not detected by SBT method using the full-length locus-specific primers SLA1-F/SLA1-R in seven Landrace pigs with Hp-28.0. Subsequently, we attempted to use a pair of sequence-specific typing primers to amplify this allele by PCR in nine Landrace parental breeding pigs (pig ID: 2922, 3037, 3093, 3111, 3112, $3219,3220,3222$, and 3241). We found clear amplified bands of the expected sizes (193 bp) were visualized in seven pigs with Hp-28.0 (except pig 3037 and 3093 with Hp-73.0).

Based on the SLA alleles identified in the parental SPF Yorkshire and Landrace pigs, 44 pairs of sequence-specific typing primers were designed to differentiate each of the 62 alleles (including $S L A-1^{\star}$ 09:01 allele) using PCR (Table S2 in Supplementary 
TABLE 1 | Alleles of five swine leukocyte antigen (SLA) loci identified in Canadian specific pathogen-free Yorkshire and Landrace pigs by the sequencebased typing (SBT) method.

\begin{tabular}{|c|c|c|c|c|c|c|c|}
\hline \multirow[t]{2}{*}{ Pig ID } & \multirow[t]{2}{*}{ Sex } & \multicolumn{5}{|c|}{ SLA allele specificity } & \multirow[t]{2}{*}{ Corresponding SLA genotype $^{a}$} \\
\hline & & $S L A-1$ & SLA-3 & $S L A-2$ & DRB1 & $D Q B 1$ & \\
\hline \multicolumn{8}{|c|}{ Landrace } \\
\hline 2906 & 암 & 07:02, 14:01 & 05:02, 04:02 & 02:02, 10:04 & 06:01, 10:01 & 06:01, 07:01:01 & Hp-32.12b/64.23 \\
\hline 2922 & 우 & $14: 01,15: 01,09: 01^{b}$ & 05:02, 07:01:02 & $10: 04,05: 03$ & 10:01 & 06:01 & Hp-64.23/28.23 \\
\hline 2959 & \& & 14:01, 08:11 & 05:02 & $10: 04,10: 06$ & $10: 01$ & 06:01 & Hp-64.23/26b.23 \\
\hline 2995 & 우 & $14: 01$ & 05:02, 04:04 & 10:04, 06:02:01 & 10:01, 06:02 & 06:01, 07:01:01 & Hp-64.23/62.12a \\
\hline 3037 & 0 & $07: 02,15: 01$ & 04:02 & 02:02 & 06:01 & 07:01:01 & $\mathrm{Hp}-32.12 \mathrm{~b} / 73.12 \mathrm{~b}$ \\
\hline 3065 & $\hat{0}$ & $14: 01$ & 05:02, 04:04 & 10:04, 06:02:01 & 10:01, 06:02 & 06:01, 07:01:01 & Hp-64.23/62.12a \\
\hline 3093 & q & 08:01, 15:01 & 07:01:01, 04:02 & 02:02, 05:02 & $10: 01,06: 01$ & 06:01, 07:01:01 & $\mathrm{Hp}-7.23 / 73.12 \mathrm{~b}$ \\
\hline 3100 & 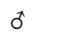 & 08:05, 08:01 & 07:01:01, 06:01 & 05:02, 05:04 & 10:01, 06:01 & 06:01, 07:01:01 & Hp-6.12b/7.23 \\
\hline 3111 & ㅇ & $15: 01,09: 01^{b}$ & 07:01:02, 04:02 & 02:02, 05:03 & 10:01, 06:01 & 06:01, 07:01:01 & Hp-28.23/73.12b \\
\hline 3112 & 암 & $15: 01,09: 01^{b}$ & 07:01:02, 04:02 & 02:02, 05:03 & 10:01, 06:01 & 06:01, 07:01:01 & Hp-28.23/73.12b \\
\hline 3141 & \& & $14: 01$ & 04:04 & 06:02:01 & 06:02 & 07:01:01 & Hp-62.12a \\
\hline 3216 & 우 & $14: 01,12: 01,13: 01$ & 05:02, 04:04 & 10:01, 06:02:01 & 10:01, 06:02 & 06:01, 07:01:01 & Hp-35.23/62.12a \\
\hline 3219 & \& & $14: 01,15: 01,09: 01^{b}$ & 05:02, 07:01:02 & 10:04, 05:03 & 10:01, 08:01 & $06: 01,02: 03$ & $\mathrm{Hp}-28.8 b / 64.23$ \\
\hline 3220 & 운 & $15: 01,09: 01^{b}$ & 07:01:02 & 05:03 & $10: 01$ & 06:01 & Hp-28.23 \\
\hline 3222 & q & $15: 01,09: 01^{b}$ & 07:01:02 & 05:03 & $10: 01$ & 06:01 & Hp-28.23 \\
\hline 3231 & o & 08:01, 07:02 & 04:02, 07:01:01 & 02:02, 05:02 & 06:01, 08:01 & 07:01:01, 02:03 & $\mathrm{Hp}-7.8 \mathrm{~b} / 32.12 \mathrm{~b}$ \\
\hline 3241 & 0 & $07: 02,15: 01,09: 01^{b}$ & 04:02, 07:01:02 & 02:02, 05:03 & 06:01, 10:01 & 06:01, 07:01:01 & Hp-28.23/32.12b \\
\hline 3242 & 0 & 04:01:01, 07:02 & 04:01, 04:02 & 02:02, 04:02:01 & 05:01, 06:01 & 02:01, 07:01:01 & Hp-4b.5/32.12b \\
\hline 3253 & \& & 08:01, 07:02 & 04:02, 07:01:01 & 02:02, 05:02 & 06:01, 08:01 & 07:01:01, 02:03 & $\mathrm{Hp}-7.8 \mathrm{~b} / 32.12 \mathrm{~b}$ \\
\hline 3255 & 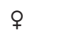 & 04:01:01, 08:01 & 07:01:01, 04:01 & 05:02, 04:02:01 & 05:01, 08:01 & 02:03, 02:01 & $\mathrm{Hp}-4 \mathrm{~b} .5 / 7.8 \mathrm{~b}$ \\
\hline 3257 & @ & 08:01, 07:02 & 04:02, 07:01:01 & 02:02, 05:02 & 06:01, 08:01 & 07:01:01, 02:03 & $\mathrm{Hp}-7.8 \mathrm{~b} / 32.12 \mathrm{~b}$ \\
\hline 3313 & ㅇ & $14: 01$ & 04:04 & 06:02:01 & 06:02 & 07:01:01 & $\mathrm{Hp}-62.12 \mathrm{a}$ \\
\hline \multicolumn{8}{|c|}{ Yorkshire } \\
\hline 4975 & \& & 08:08, 08:11 & 05:02 & $10: 06,10: 05$ & $10: 01$ & 06:01 & Hp-26a.23/26b.23 \\
\hline 5045 & \& & 04:01:01, 08:11 & 04:01, 05:02 & 10:06, 04:01 & 10:01, 02:01:01 & 06:01, 04:01:01 & Hp-26b.23/4a.4a \\
\hline 5075 & $\hat{0}$ & 04:01:01, 08:11 & 04:01, 05:02 & 10:06, 04:01 & 10:01, 02:01:01 & 06:01, 04:01:01 & Hp-26b.23/4a.4a \\
\hline 5076 & 0 & 04:01:01, 12:01, 13:01 & 04:01, 05:02 & 04:01, 10:01 & 02:01:01, 10:01 & 04:01:01, 06:01 & Hp-4a.4a/35.23 \\
\hline 5187 & q & 01:01, 08:11 & 05:02, 01:01 & 01:01, 10:06 & 04:02, 10:01 & 02:02, 06:01 & $\mathrm{Hp}-1 \mathrm{a} .15 \mathrm{~b} / 26 \mathrm{~b} .23$ \\
\hline 5194 & 0 & 04:01:01, 12:01, 13:01 & 04:01, 05:02 & 10:01, 04:01 & 10:01, 02:01:01 & 06:01, 04:01:01 & Hp-4a.4a/35.23 \\
\hline 5208 & 우 & 11:03, 08:11, 08:12 & 05:02, 05:03:02 & $16: 03,10: 06$ & 09:01:01, 10:01 & 06:01, 09:01 & Hp-26b.23/63.27 \\
\hline 5227 & \& & 11:03, 08:11, 08:12 & 05:02, 05:03:02 & $16: 03,10: 06$ & 09:01:01, 10:01 & 06:01, 09:01 & Hp-26b.23/63.27 \\
\hline 5238 & 우 & 04:01:01, 08:07 & 04:01, 03:06 & 04:01, 09:03 & 02:01:01 & 02:01, 04:01:01 & Hp-4a.4a/58.2 \\
\hline 5247 & q & 08:08, 07:04 & 05:06, 05:02 & $10: 05,09: 05$ & $07: 01,10: 01$ & 02:01, 06:01 & Hp-26a.23/37.24 \\
\hline 5327 & o & 04:01:01, 07:03 & 04:01, 06:01 & 05:05, 04:01 & 06:07, 02:01:01 & 02:12, 04:01:01 & $\mathrm{Hp}-4 \mathrm{a} .4 \mathrm{a} / 21.22$ \\
\hline 5341 & 운 & 11:03, 08:11, 08:12 & 05:02, 05:03:02 & $16: 03,10: 06$ & 09:01:01, 10:01 & 06:01, 09:01 & Hp-26b.23/63.27 \\
\hline 5343 & 우 & 11:03, 08:11, 08:12 & 05:02, 05:03:02 & $16: 03,10: 06$ & 09:01:01, 10:01 & 06:01, 09:01 & Hp-26b.23/63.27 \\
\hline 5344 & o & $01: 01,08: 11$ & 01:01, 05:02 & 01:01, 10:06 & $04: 02,10: 01$ & $02: 02,06: 01$ & $\mathrm{Hp}-1 \mathrm{a} .15 \mathrm{~b} / 26 \mathrm{~b} .23$ \\
\hline 5346 & 우 & 01:01, 08:11 & 01:01, 05:02 & $01: 01,10: 06$ & 04:02, 10:01 & 02:02, 06:01 & $\mathrm{Hp}-1 \mathrm{a} .15 \mathrm{~b} / 26 \mathrm{~b} .23$ \\
\hline
\end{tabular}

aDesignation refers to Table 3

'SSLA-1*09:01 was detected by PCR-sequence specific primers but missed by mRNA SBT.

Material). The results of PCR-SSP SLA typing of the 37 founding pigs were consistent with the SBT data (Table 1). Subsequently, all $\mathrm{F} 1$ progeny pigs were genotyped using the complete set of primers to assign alleles to haplotypes based on inheritance and segregation patterns by descent. A representative gel image showing the typing of Yorkshire and Landrace pigs is shown in Figure 1. The SLA genotypes of each individual were determined according to the allele-specific bands. The results showed that a total of 19 SLA haplotypes were identified in SPF Yorkshire and Landrace pigs at the molecular level, including 17 class I haplotypes and 11 class II haplotypes. Official ISAG haplotype designations were assigned by the SLA Nomenclature Committee (Table 3). Among these, three class I haplotypes, Hp-37.0, 63.0, and 73.0, appeared to be novel and have not previously been reported in other pig populations (Table 4). The most common haplotype Hp-26b.23 (SLA-1*08:11-SLA-3*05:02-SLA-2*10:06$\left.D R B 1^{\star} 10: 01-D Q B 1^{\star} 06: 01\right)$ and Hp-32.12b (SLA-1*07:02-SLA$\left.3^{\star} 04: 02-S L A-2^{\star} 02: 02-D R B 1^{\star} 06: 01-D Q B 11^{\star} 07: 01: 01\right)$ was identified in 76 Yorkshire and 74 Landrace pigs with frequencies of 29.7 and $20.7 \%$, respectively. Two $S L A-1$ alleles were observed in three class I haplotypes in pigs: Hp-28.0 (SLA-1*09:01, SLA-1*15:01), Hp-35.0 (SLA-1*12:01, SLA$\left.1^{\star} 13: 01\right)$, and Hp-63.0 (SLA-1*08:12, SLA-1*11:03). Several haplotypes appeared to be the result of crossovers between class I and class II regions, e.g., Hp-7.8b, comprising class I haplotype Hp-7.23 and class II haplotype Hp-28.8b. Hp-28.8b and 28.23 haplotypes comprised different sets of class II alleles but shared the same class I alleles. Hp-7.23, 26a.23, 26b.23, 28.23, 35.23, and 64.23 haplotypes comprised different sets of class I alleles but shared the same class II alleles. 
TABLE 2 | The alleles identified in Canadian specific pathogen-free Yorkshire and Landrace pigs which confirmed the unassigned alleles and standardized nomenclatures of the previously unconfirmed alleles in the GenBank database.

\begin{tabular}{|c|c|c|c|c|}
\hline \multirow[t]{2}{*}{ Locus } & \multirow[t]{2}{*}{ Allele } & \multicolumn{2}{|c|}{$\begin{array}{c}\text { GenBank accession } \\
\text { number }\end{array}$} & \multirow{2}{*}{$\begin{array}{l}\text { Official } \\
\text { International } \\
\text { Society for } \\
\text { Animal Genetics } \\
\text { designation }\end{array}$} \\
\hline & & $\begin{array}{l}\text { Submitted in } \\
\text { this study }\end{array}$ & $\begin{array}{l}\text { Previously } \\
\text { submitted }\end{array}$ & \\
\hline \multicolumn{5}{|c|}{ The unassigned allele with complete coding sequence } \\
\hline \multirow[t]{2}{*}{$S L A-1$} & $\begin{array}{l}\text { SLA-1*dxbm05 } \\
\text { SLA-1*'WZs01 } \\
\text { SLA-1*bm04 }\end{array}$ & KU754554 & $\begin{array}{l}\text { KX056221 } \\
\text { KT194212 } \\
\text { KT350995 }\end{array}$ & $S L A-1^{\star} 07: 04$ \\
\hline & - & KU754558 & AK351685 & $S L A-1^{*} 08: 11$ \\
\hline \multirow[t]{2}{*}{ SLA-2 } & $\begin{array}{l}- \\
- \\
-\end{array}$ & KU754568 & $\begin{array}{l}\text { DQ992497 } \\
\text { DQ992498 } \\
\text { DQ992499 }\end{array}$ & $S L A-2^{*} 16: 03$ \\
\hline & - & KU754570 & AK239592 & $S L A-2^{*} 10: 06$ \\
\hline \multicolumn{5}{|c|}{ The unconfirmed allele with complete coding sequence } \\
\hline$S L A-1$ & $\begin{array}{l}\text { SLA-1*08pt13 } \\
\text { SLA-1*08sk11 } \\
\text { SLA-1*11jh02 }\end{array}$ & $\begin{array}{l}\text { KU953375 } \\
\text { KU754548 } \\
\text { KU754550 }\end{array}$ & $\begin{array}{l}\text { EU440337 } \\
\text { EU440332 } \\
\text { DQ883209 }\end{array}$ & $\begin{array}{l}\text { SLA-1*08:07 } \\
\text { SLA-1*08:08 } \\
\text { SLA-1*11:03 }\end{array}$ \\
\hline SLA-2 & $\begin{array}{l}\text { SLA-2*w09pt22 } \\
\text { SLA-2*10es21 } \\
\text { SLA-2*10sk21 }\end{array}$ & $\begin{array}{l}\text { KU953376 } \\
\text { KU754565 } \\
\text { KU754566 }\end{array}$ & $\begin{array}{l}\text { EU432085 } \\
\text { EU432090 } \\
\text { EU432083 }\end{array}$ & $\begin{array}{l}S L A-2^{*} 09: 03 \\
S L A-2^{*} 10: 04 \\
S L A-2^{*} 10: 05\end{array}$ \\
\hline SLA-3 & $\begin{array}{l}\text { SLA-3*03pt31 } \\
\text { SLA-3*hb06 }\end{array}$ & $\begin{array}{l}\text { KU953377 } \\
\text { KU754583 }\end{array}$ & $\begin{array}{l}\text { EU432095 } \\
\text { AP009559 }\end{array}$ & $\begin{array}{l}\text { SLA-3*03:06 } \\
\text { SLA- } 3^{*} 04: 04\end{array}$ \\
\hline \multicolumn{5}{|c|}{ The unconfirmed allele with partial coding sequence } \\
\hline$S L A-1$ & SLA-1*rh03 & KU754555 & AF074427 & $S L A-1^{\star} 07: 03$ \\
\hline$S L A-2$ & $S L A-2 * 05$ rh03 & KU754569 & AF074428 & $S L A-2^{\star} 05: 05$ \\
\hline DRB1 & $D R B 1^{\star} 06 \mathrm{sL} 47$ & KU754601 & L08847 & $D R B 1^{\star} 06: 07$ \\
\hline \multirow[t]{2}{*}{ DQB1 } & $D Q B 1 * 0203$ & KU754591 & $\begin{array}{l}\text { AB012093 } \\
\text { AF113970 }\end{array}$ & $D Q B 1^{*} 02: 03$ \\
\hline & $D Q B 1 * 0204$ & KU754590 & $\begin{array}{l}\text { L08844 } \\
\text { EU039916 }\end{array}$ & $D Q B 1^{*} 02: 12$ \\
\hline
\end{tabular}

Among the 367 pigs SLA genotyped in this study, a total of three crossovers were identified within the SLA region. The details of each crossover are shown schematically in Figure 2. One crossover occurred within the class I region, resulting in one new recombinant haplotype (Figure $2 \mathrm{~A}$ ), with a haplotype frequency of $0.3 \%$. Two crossovers involved exchanges between class I and class II regions, resulting in two new recombinant haplotypes Hp-64.8b and Hp-26b.4a (Figure 2B), with haplotype frequencies of 0.3 and $0.4 \%$, respectively.

\section{SLA Class I Molecule Clustering}

To illustrate the important differences between sequence- and function-based clustering, we generated clusters of SLA class I alleles by functional clustering using the MHCcluster method. Nineteen identified frequent class I alleles in Yorkshire and Landrace pigs were chosen for analysis, including six SLA-1 alleles, six SLA-2 alleles, and seven SLA-3 alleles, which already exists in the MHC allele lists of MHCcluster Server. MHCcluster analysis was based on the comparison of predicted binding motifs for each individual SLA molecule and gave an unrooted tree visualization of functional peptide-binding similarities. This analysis demonstrated that clustering to a very high degree produced four distinct specificity groups (Figure 3). However, some SLA class I molecules were not well characterized by the specificities of four supertypes. Each of four clusters consisted of SLA class I molecules with highly divergent specificities, and some molecules, e.g., $S L A-1^{\star} 12: 01, S L A-3^{\star} 01: 01, S L A-2^{\star} 02: 02$, and $S L A-2^{\star} 10: 01$, were poorly characterized by the specificities of four supertypes. Moreover, the sequence homologies between $S L A-1^{\star} 01: 01$ and $S L A-2^{\star}$ 05:02 molecules were $89.7 \%$ at the amino acid level, but examination of the binding specificities represented by the sequence logos that described the predicted binding motif for each SLA molecule revealed that $S L A-1^{\star} 01: 01$ and $S L A-2^{\star}$ 05:02 molecules were functionally similar compared with other molecules, e.g., $S L A-1^{\star} 04: 01$ and $S L A-1^{\star} 13: 01$, which shared 97.3\% similarity at the amino acid level. The peptide-binding motifs of $S L A-3^{\star} 01: 01$ was shown to have a mixed $S L A-3^{\star} 04: 02$ and $S L A-3^{\star} 05: 02 / 05: 03$ specificity matching $S L A-3^{\star} 04: 02$ at the $\mathrm{N}$-terminal and $S L A-3^{\star} 05: 02 / 05: 03$ at the C-terminal ends. These molecules all had predicted accuracy values of 1.00 , indicating that the molecules were well characterized by the peptide-binding data. The calculated binding motifs were thus considered to have a high likelihood of giving a correct representation of the specificity of the molecules. In addition, although $S L A-1^{\star} 04: 01$ and $S L A-1^{\star} 13: 01$ molecules shared close to $97.3 \%$ similarity, differing by only nine amino acid substitutions, they appeared to have functional differences, despite being classified in a single cluster using functional clustering.

\section{DISCUSSION}

Specific pathogen-free Yorkshire and Landrace pigs were imported from Canadian Genesus incorporated in 2014 and represent the most important large animal model for studying host immune responses to viruses in China. The SLA complex consists of many important immune-related genes and has been repeatedly associated with variations in immunological and physiological performances. Therefore, it is essential to define the SLA alleles and haplotypes of these pigs molecularly, to use them preferably as classical laboratory animals for clarifying the molecular mechanisms responsible for host immune responses. In this study, we identified and assigned 43 class I and 18 class II alleles at five SLA loci representing 17 class I haplotypes and 11 class II haplotypes, by the SBT and PCR-SSP methods. The official ISAG haplotype designations were assigned by the SLA Nomenclature Committee. These submissions confirmed and defined many previously unconfirmed alleles and haplotypes. The SLA Nomenclature Committee adopted the naming protocol for human leukocyte antigen alleles and has converted the SLA nomenclature system to better resemble the human leukocyte antigen system. Currently, the confirmed alleles in this study have been released in updated IPD-MHC SLA database [Release 2.0.0.3 (2016-11-03)]. Among these haplotypes, three class I haplotypes, Hp-37.0, 63.0, and 73.0, appeared to be novel and have not previously been reported in other pig breeds, although the $S L A-1^{\star} 07: 04$ allele was found in the Chinese Bama miniature pig (KX056221) and Wuzhishan miniature pig (KT194212), and the SLA-2*16:03 allele was obtained from the clone KNP2006 (DQ992497)/KNP2007 (DQ992498)/KNP2008 (DQ992499), constructed from Korean native pigs. This suggests that these pigs might also carry the corresponding haplotypes. Inheritance 

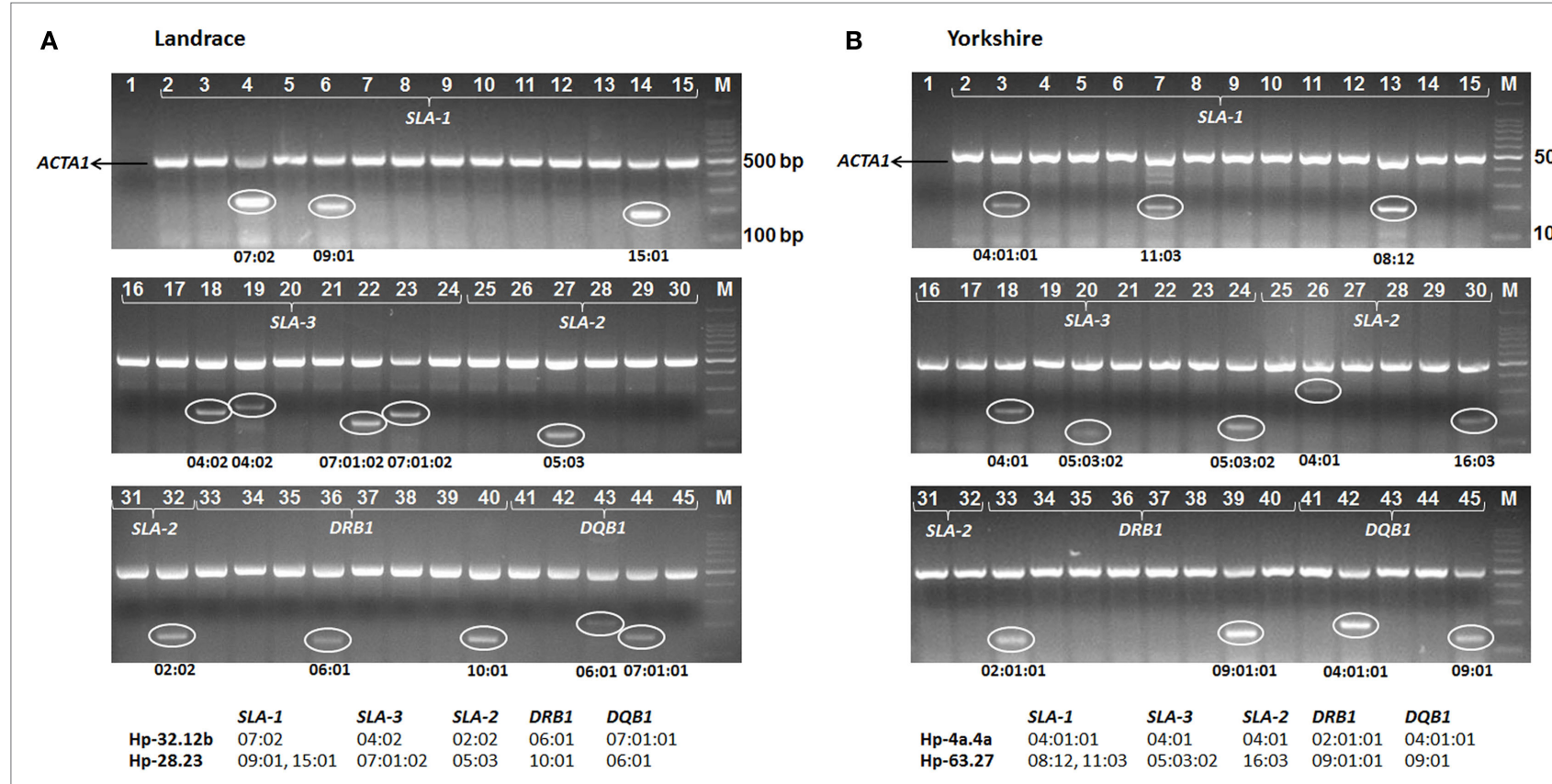

FIGURE 1 | Examples of swine leukocyte antigen (SLA) genotyping in Canadian specific pathogen-free Yorkshire and Landrace pigs at five loci (SLA-1, SLA-3, SLA-2, DRB1, and DQB1) by PCR-sequence-specific primers using the full primer set (44 primer pairs, lane 2 through 45 , specific for each alleles identified in pigs) (Table $\mathbf{S 2}$ in Supplementary Material). Negative controls with all reagents except DNA were used to check for contamination (lane 1). Positive internal control primers (porcine ACTA1, 516 bp) were multiplexed into each reaction to check for adequate amplification (upper band). The presence of a smaller PCR product indicates the sample was positive for the allele(s) in the corresponding reaction (lower band). Product sizes of each allele-specific primer are given in Table S2 in Supplementary Material. Pig samples shown here are [(A) Landrace] SLA Hp-32.12b/28.23 (Table 3), with specific amplifications in lanes 4 (SLA-1*07:02), 6 (SLA-1*09:01), 14 (SLA-1*15:01), 18 (SLA-3*04:02), 19 (SLA-3*04:02), 22 (SLA-3*07:01:02), 23 (SLA-3*07:01:02), 27 (SLA-2*05:03), 32 (SLA-2*02:02), 36 (DRB1*06:01), 40 (DRB1*10:01), 43 (DQB1*06:01), and 44 (DQB1*07:01:01); and [(B) Yorkshire] SLA Hp-4a.4a/63.27 (Table 3), with specific amplifications in lanes 3 (SLA-1*04:01:01), 7 (SLA-1*11:03), 13 (SLA-1*08:12), 18 (SLA-3*04:01), 20 (SLA-3*05:03:02), 24 (SLA-3*05:03:02), 26 (SLA-2*04:01), 30 (SLA-2*16:03), 33 (DRB1*02:01:01), 39 (DRB1*09:01:01), 42 (DQB1*04:01:01), and 45 (DQB1*09:01). M, 100 bp PCR marker (TaKaRa, Dalian, China).

and segregation patterns by descent demonstrated the presence of a duplicated SLA-1 locus in Hp-28.0, Hp-35.0, and Hp-63.0. In particular, the $S L A-1^{\star}$ 09:01 allele was not detected by SBT method. However, it has been found that the SLA-1 $a^{\star} 09: 01$ and $S L A-1 b^{\star} 15: 01$ alleles of Hp-28.0 are mapped between a 149$\mathrm{kb}$ genomic segment of the SLA class I gene clusters by BAC sequencing analyses (20), and our results of PCR-SSP SLA typing were consistent with the previous findings.

Haplotype Hp-4.0 (4a.0 or $4 \mathrm{~b} .0$ ) was the more prevalent class I haplotype in Yorkshire, Landrace, and crossbred progeny between Yorkshire and Landrace pigs. This is consistent with previous reports identifying $\mathrm{Hp}-4.0$ as commonly present in swine breeds worldwide, including NIH, Duroc, Meishan, Yucatan, Danish pigs, German purebred Landrace, and outbred pig populations, and "PK13, PK15" cell lines (5, 14, 16, 19, $21,28,32,33)$, indicating that $\mathrm{Hp}-4.0$ is a valuable SLA class I haplotype that has survived long-term evolutionary selection. No novel class II haplotypes were identified in SPF Yorkshire and Landrace pigs. Hp- 0.23 was the most common SLA class II haplotype in this study and was shared by several other pig populations, including Microminipigs, the IU-pig model, Landrace $\times$ Yorkshire, Guizhou miniature pigs, Korean native pigs, Big pigs, German purebred Landrace, and Pietrain pigs (17, 26, 31, 32, 34, 35, 38, 39) (Table 4). This suggests that Yorkshire and Landrace pigs may share some common genetic background with these breeds.

Six SLA class I haplotypes, Hp-4b.0, Hp-26a.0, Hp-32.0, Hp-35.0, Hp-58.0, and Hp-64.0, identified in this study had been also identified in six commercially available porcine cell lines, ESK-4, PK13, PK15, PT-K75, SK-RST, and ST (21). In addition, two class I haplotypes (Hp-32.0 and Hp-35.0) and a class II haplotype (Hp-0.23) had also been identified in the crossbred IU-pig model for use in xenotransplant studies (38). This suggests that Yorkshire or Landrace pigs might have been commonly used to involve in the establishment of some porcine cell lines and specific animal models.

We also found recombination events in the SLA region. One recombinant within the SLA class I region and two between class I and class II regions were identified in 367 Yorkshire and Landrace pigs. Three SLA recombinants were previously identified in 281 Chinese Bama miniature pigs (15), and six crossovers were also identified within the SLA region in 466 Sinclair and Hanford pigs (27). A novel line of miniature pigs, Microminipigs, which have a considerably smaller body size than other miniature pig breeds, such as Clawn, Yucatan, NIH, Sinclair, and Hanford, also have three recombinant haplotypes (34). This suggests the existence of recombination hotspots in the SLA class I and class III regions. Crossover within the SLA class II region has not yet been found. 
TABLE 3 | Swine leukocyte antigen (SLA) haplotypes and corresponding alleles identified in Canadian specific pathogen-free Yorkshire and Landrace pigs.

\begin{tabular}{|c|c|c|c|c|c|c|c|c|c|}
\hline \multirow{3}{*}{$\begin{array}{l}\text { SLA haplotype [International Society for Animal Genetics } \\
\text { (ISAG) Nomenclature] }\end{array}$} & \multicolumn{3}{|c|}{ Class I loci } & \multicolumn{2}{|c|}{ Class II loci } & \multicolumn{4}{|c|}{ No. of pigs/haplotype frequency (\%) } \\
\hline & \multirow[t]{2}{*}{$S L A-1$} & \multirow[t]{2}{*}{ SLA-3 } & \multirow[t]{2}{*}{$S L A-2$} & \multirow[t]{2}{*}{ DRB1 } & \multirow[t]{2}{*}{$D Q B 1$} & \multirow{2}{*}{$\frac{Y^{a}}{2 n=256}$} & \multirow{2}{*}{$\begin{array}{c}\mathrm{L}^{\mathrm{a}} \\
2 n=358\end{array}$} & \multirow{2}{*}{$\begin{array}{c}Y \times L^{a} \\
2 n=62\end{array}$} & \multirow{2}{*}{$\begin{array}{c}\mathrm{L} \times \mathrm{Ya}^{\mathrm{a}} \\
2 n=58\end{array}$} \\
\hline & & & & & & & & & \\
\hline Hp-1a.15b & 01:01 & 01:01 & 01:01 & 04:02 & 02:02 & $25 / 9.8$ & & & \\
\hline $\mathrm{Hp}-4 \mathrm{a} .4 \mathrm{a}$ & 04:01:01 & 04:01 & 04:01 & 02:01:01 & 04:01:01 & $67 / 26.2$ & & $17 / 27.4$ & $9 / 15.5$ \\
\hline Hp-4b.5 & 04:01:01 & 04:01 & 04:02:01 & 05:01 & 02:01 & & $26 / 7.3$ & & \\
\hline $\mathrm{Hp}-6.12 \mathrm{~b}$ & 08:05 & 06:01 & 05:04 & 06:01 & 07:01:01 & & $26 / 7.3$ & & \\
\hline $\mathrm{Hp}-7.8 \mathrm{~b}$ & 08:01 & 07:01:01 & 05:02 & 08:01 & $02: 03$ & & $36 / 10.0$ & $5 / 8.1$ & \\
\hline $\mathrm{Hp}-7.23$ & 08:01 & 07:01:01 & 05:02 & 10:01 & 06:01 & & $31 / 8.6$ & & \\
\hline $\mathrm{Hp}-21.22$ & 07:03 & 06:01 & 05:05 & 06:07 & $02: 12$ & 18/7.0 & & $4 / 6.5$ & \\
\hline Hp-26a.23 & 08:08 & 05:02 & $10: 05$ & 10:01 & 06:01 & $7 / 2.7$ & & & $7 / 12.1$ \\
\hline Hp-26b.23 & 08:11 & 05:02 & 10:06 & 10:01 & 06:01 & $76 / 29.7$ & $12 / 3.4$ & & $13 / 22.4$ \\
\hline Hp-28.8b & $09: 01^{b}, 15: 01$ & 07:01:02 & 05:03 & 08:01 & 02:03 & & $6 / 1.7$ & & \\
\hline Hp-28.23 & $09: 01^{b}, 15: 01$ & 07:01:02 & 05:03 & $10: 01$ & 06:01 & & $48 / 13.4$ & $11 / 17.7$ & $14 / 24.1$ \\
\hline $\mathrm{Hp}-32.12 \mathrm{~b}$ & 07:02 & 04:02 & 02:02 & 06:01 & 07:01:01 & & $74 / 20.7$ & $4 / 6.5$ & $15 / 25.9$ \\
\hline Hp-35.23 & $12: 01,13: 01$ & 05:02 & 10:01 & $10: 01$ & 06:01 & $19 / 7.4$ & $6 / 1.7$ & 10/16.1 & \\
\hline $\mathrm{Hp}-37.24$ & 07:04 & 05:06 & 09:05 & 07:01 & 02:01 & $11 / 4.3$ & & & \\
\hline Hp-58.2 & 08:07 & 03:06 & 09:03 & 02:01:01 & 02:01 & $6 / 2.3$ & & & \\
\hline $\mathrm{Hp}-62.12 \mathrm{a}$ & $14: 01$ & 04:04 & 06:02:01 & 06:02 & 07:01:01 & & $27 / 7.5$ & 10/16.1 & \\
\hline Hp-63.27 & 08:12, 11:03 & 05:03:02 & $16: 03$ & 09:01:01 & 09:01 & 26/10.2 & & & \\
\hline Hp-64.23 & $14: 01$ & 05:02 & $10: 04$ & $10: 01$ & 06:01 & & $33 / 9.2$ & $1 / 1.6$ & \\
\hline $\mathrm{Hp}-73.12 \mathrm{~b}$ & 15:01 & 04:02 & 02:02 & 06:01 & 07:01:01 & & $31 / 8.6$ & & \\
\hline \multicolumn{10}{|l|}{ Recombinant haplotype } \\
\hline $\mathrm{Hp}-N A .12 b^{c}$ & $09: 01^{b}, 15: 01$ & 04:02 & 02:02 & 06:01 & 07:01:01 & & $1 / 0.3$ & & \\
\hline $\mathrm{Hp}-64.8 \mathrm{~b}$ & 14:01 & 05:02 & $10: 04$ & 08:01 & 02:03 & & $1 / 0.3$ & & \\
\hline $\mathrm{Hp}-26 \mathrm{~b} .4 \mathrm{a}$ & 08:11 & 05:02 & $10: 06$ & 02:01:01 & 04:01:01 & $1 / 0.4$ & & & \\
\hline
\end{tabular}

aY, Yorkshire; L, Landrace; $Y \times L$, Yorkshire Landrace cross; $L \times Y$, Landrace Yorkshire cross.

${ }^{b} S L A-1{ }^{*} 09: 01$ was detected by PCR-sequence-specific primers but missed by mRNA sequence-based typing.

'NA, official designation of the crossover class I haplotypes was not assigned by the ISAG SLA Nomenclature Committee.

Importantly, these pig breeds will be useful for studying the effects of selected differences at SLA class I and/or class II loci on parameters of transplantation immunity.

Yorkshire and Landrace pig breeds are distributed worldwide, and this study may not have fully revealed the extent of SLA diversity in these breeds because of specific selection in different countries, the possibility of founder effects, the relatively small sample size, and the breeding schemes for Yorkshire and Landrace pigs. However, the results provide the first data for the SLA haplotype repertoire of SPF Yorkshire and Landrace pigs and improve our knowledge of the allelic architecture of the SLA system. Previous studies have also shown that the SLA protein can inhibit natural killer-mediated cytotoxicity (40). Therefore, several resource populations of pigs with well-characterized SLA antigens are now available worldwide for experiments in various disciplines, with special emphasis on xenotransplantation and immunologic mechanism studies.

The peptide-binding function of only seven already known SLA class I alleles identified in Danish swine herds have been analyzed using the MHCcluster method (19). The functional diversity of the majority of SLA class I alleles have never been comprehensively compared up to now. Canadian SPF Yorkshire and Landrace pigs are more suitable as laboratory animal models for biomedical research because of their unique advantages. In order to obtain more extensive applications for these two swine species and decide which SLA proteins to include in future functional analyses, it is significant and necessary to comparative analyze the functional diversity of SLA class I alleles identified in this study. We chose 19 identified frequent SLA class I alleles in SPF Yorkshire and Landrace pigs for clustering analysis using the MHCcluster method. Even though the application of this method is limited to comparing functional similarities between large sets of MHC molecules, it is an effective visual tool combining functional clustering and visualization of predicted binding motifs, allowing for direct functional mapping of MHC molecules. Most of the polymorphism of SLA class I proteins is resident in the peptide-binding groove. Crystal structural analysis indicated that the peptide-binding groove of SLA class I molecules contains six pockets and these pockets play critical biochemical roles in determining the peptide-binding motif of SLA class I alleles (6, 41). SLA molecules perform the important functions of sampling and displaying peptides to $\mathrm{T}$ cells. The binding of an appropriate peptide to SLA is the single most selective event in antigen presentation. Any search for immunogenic epitopes should therefore consider the identification of SLA-binding peptides to be a high priority. However, the binding of different SLA alleles and different classes of peptide was determined by the fit between these "pockets" and "anchor" residues in the peptides (4-6). Only a fraction of peptides that fit the simple kind of motif used actually bind the corresponding class I molecule with measurable affinities. Therefore, the characterization of the peptide-binding motifs of SLA class I proteins is beneficial to identify the cognate 
TABLE 4 | Swine leukocyte antigen (SLA) class I and class II haplotypes identified in Canadian specific pathogen-free Yorkshire and Landrace pigs and in swine breeds and cell lines with published identical haplotypes.

\begin{tabular}{|c|c|c|c|c|c|}
\hline $\begin{array}{l}\text { SLA class I } \\
\text { haplotype }\end{array}$ & Breed $^{a}$ & Reference & $\begin{array}{l}\text { SLA class II } \\
\text { haplotype }\end{array}$ & Breed $^{\mathrm{a}}$ & Reference \\
\hline $\mathrm{Hp}-1 \mathrm{a} .0$ & $\begin{array}{l}\text { Large white } \\
\text { KSU, PCV, Big pig } \\
\text { Pietrain }^{\mathrm{b}} \\
\text { Danish pigs }^{\mathrm{b}} \\
\text { German Landrace }^{\mathrm{b}}\end{array}$ & $\begin{array}{l}\text { Renard et al. (25) } \\
\text { Ho et al. (16) } \\
\text { Essler et al. (31) } \\
\text { Pedersen et al. (19) } \\
\text { Gimsa et al. (32) }\end{array}$ & Hp-0.2 & $\begin{array}{l}\text { Landrace } \times \text { Yorkshire } \\
\text { Sinclair, Hanford } \\
\text { NIH } \\
\text { MPK } \\
\text { PCV, Big pig, KSU } \\
\text { SNU } \\
\text { Du, Y } \times \text { L, La, NIH, Os, } \\
\text { SNU, Yo }\end{array}$ & $\begin{array}{l}\text { Le et al. (26) } \\
\text { Ho et al. (27) } \\
\text { Smith et al. (28) } \\
\text { Ho et al. (21) } \\
\text { Ho et al. (17) } \\
\text { Yeom et al. (29) } \\
\text { Le et al. (30) }\end{array}$ \\
\hline $\mathrm{Hp}-4 \mathrm{a} .0$ & $\begin{array}{l}\mathrm{NIH} \\
\text { Duroc } \\
\text { Meishan }^{\mathrm{C}}\end{array}$ & $\begin{array}{l}\text { Oleksiewicz et al.; Smith et al. }(5,28) \\
\text { Immuno Polymorphism Database (IPD)-MHC } \\
\text { database } \\
\text { Ho et al. (14) }\end{array}$ & Hp-0.4a & $\begin{array}{l}\text { Landrace } \times \text { Yorkshire } \\
\mathrm{NIH}\end{array}$ & $\begin{array}{l}\text { Le et al. (26) } \\
\text { Smith et al. (28) }\end{array}$ \\
\hline Hp-4b.0 & $\begin{array}{l}\text { PK13, PK15 } \\
\text { Yucatan }\end{array}$ & $\begin{array}{l}\text { Ho et al. (21) } \\
\text { Smith et al. (28) }\end{array}$ & & $\begin{array}{l}\text { Big pig }{ }^{b} \\
Y \times L, N I H\end{array}$ & $\begin{array}{l}\text { Ho et al. (17) } \\
\text { Le et al. (30) }\end{array}$ \\
\hline $\mathrm{Hp}-4.0$ & $\begin{array}{l}\text { KSU, PCV, Big pig } \\
\text { Danish pigs }^{b} \\
\text { Yucatan }^{b} \\
\text { German Landrace }^{b}\end{array}$ & $\begin{array}{l}\text { Ho et al. (16) } \\
\text { Pedersen et al. (19) } \\
\text { Choi et al. (33) } \\
\text { Gimsa et al. (32) }\end{array}$ & & & \\
\hline Hp-6.0 & $\begin{array}{l}\text { Microminipig } \\
\text { Yucatan } \\
\text { Big pig }^{\mathrm{b}} \\
\text { Danish pigs } \\
\text { German Landrace }^{\mathrm{b}}\end{array}$ & $\begin{array}{l}\text { Ando et al. (34) } \\
\text { Smith et al.; Choi et al. }(28,33) \\
\text { Ho et al. (16) } \\
\text { Pedersen et al. (19) } \\
\text { Gimsa et al. (32) }\end{array}$ & Hp-0.5 & $\begin{array}{l}\text { Landrace } \times \text { Yorkshire } \\
\text { PK13, PK15 } \\
\text { Yucatan } \\
\text { PCV } \\
\text { Y × L, La, Os, Yo }\end{array}$ & $\begin{array}{l}\text { Le et al. (26) } \\
\text { Ho et al. (21) } \\
\text { Smith et al.; Choi et al. (28, 33) } \\
\text { Ho et al. (17) } \\
\text { Le et al. (30) }\end{array}$ \\
\hline $\mathrm{Hp}-7.0$ & $\begin{array}{l}\text { Korean native pig } \\
\text { Yucatan } \\
\text { PCV } \\
\text { Danish pigs } \\
\text { German Landrace }\end{array}$ & $\begin{array}{l}\text { Cho et al. (35) } \\
\text { Smith et al. (28) } \\
\text { Ho et al. (16) } \\
\text { Pedersen et al. (19) } \\
\text { Gimsa et al. (32) }\end{array}$ & Hp-0.8b & $\begin{array}{l}\text { Landrace } \times \text { Yorkshire } \\
P C V^{b} \\
Y \times L \\
\text { German Landrace }^{b}\end{array}$ & $\begin{array}{l}\text { Le et al. (26) } \\
\text { Ho et al. (17) } \\
\text { Le et al. (30) } \\
\text { Gimsa et al. (32) }\end{array}$ \\
\hline Hp-21.0 & $\begin{array}{l}\text { Commercial breeds } \\
\text { PCV, Big pig }\end{array}$ & $\begin{array}{l}\text { IPD-MHC database } \\
\text { Ho et al. (16) }\end{array}$ & $\begin{array}{l}\mathrm{Hp}-0.12 \mathrm{a} \\
\mathrm{Hp}-0.12\end{array}$ & $\begin{array}{l}\text { Sinclair } \\
\text { Pietrain }^{b} \\
\text { PCV, Big pig } \\
\text { German Landrace }^{b}\end{array}$ & $\begin{array}{l}\text { Ho et al. (27) } \\
\text { Essler et al. (31) } \\
\text { Ho et al. (17) } \\
\text { Gimsa et al. (32) }\end{array}$ \\
\hline $\begin{array}{l}\text { Hp-26a.0 } \\
\text { Hp-26.0 }\end{array}$ & $\begin{array}{l}\text { SK-RST } \\
\text { KSU }^{\mathrm{b}} \\
\text { Pietrain }^{\mathrm{b}} \\
\text { Danish pigs } \\
\text { German Landrace }^{\mathrm{b}}\end{array}$ & $\begin{array}{l}\text { Ho et al. (21) } \\
\text { Ho et al. (16) } \\
\text { Essler et al. (31) } \\
\text { Pedersen et al. (19) } \\
\text { Gimsa et al. (32) }\end{array}$ & $\mathrm{Hp}-0.15 b$ & $\begin{array}{l}\text { Landrace } \times \text { Yorkshire } \\
\text { Banna } \\
\text { PCV, Big pig, KSU } \\
\text { Ld, Yo }\end{array}$ & $\begin{array}{l}\text { Le et al. (26) } \\
\text { Zeng et al.; Zeng and Zeng }(36,37) \\
\text { Ho et al. (17) } \\
\text { Le et al. (30) }\end{array}$ \\
\hline Hp-28.0 & $\begin{array}{l}\text { Landrace } \\
\text { Pietrain }^{\mathrm{b}} \\
\text { German Landrace }^{\mathrm{b}}\end{array}$ & $\begin{array}{l}\text { Tanaka-Matsuda et al. (20) } \\
\text { Essler et al. (31) } \\
\text { Gimsa et al. (32) }\end{array}$ & Hp-0.22 & PCV, Big pig, MYb & Ho et al. (17) \\
\hline Hp-32.0 & $\begin{array}{l}\text { IU-pig model } \\
\text { ST } \\
\text { Big pig } \\
\text { Pietrain } \\
\text { Danish pigs } \\
\text { German Landrace }^{b}\end{array}$ & $\begin{array}{l}\text { Reyes et al. (38) } \\
\text { Ho et al. (21) } \\
\text { Ho et al. (16) } \\
\text { Essler et al. (31) } \\
\text { Pedersen et al. (19) } \\
\text { Gimsa et al. (32) }\end{array}$ & Hp-0.23 & $\begin{array}{l}\text { Microminipig } \\
\text { IU-pig model } \\
\text { Landrace } \times \text { Yorkshire } \\
\text { Guizhou } \\
\text { Korean native pig } \\
\text { Big pig } \\
\text { Pietrain } \\
\text { Y } \times \text { L, Yo } \\
\text { German Landrace }^{b}\end{array}$ & $\begin{array}{l}\text { Ando et al. (34) } \\
\text { Reyes et al. (38) } \\
\text { Le et al. (26) } \\
\text { Liu et al. (39) } \\
\text { Cho et al. (35) } \\
\text { Ho et al. (17) } \\
\text { Essler et al. (31) } \\
\text { Le et al. (30) } \\
\text { Gimsa et al. (32) }\end{array}$ \\
\hline $\mathrm{Hp}-35.0$ & $\begin{array}{l}\text { Bama } \\
\text { Microminipig } \\
\text { IU-pig model } \\
\text { Pietrain } \\
\text { PT-K75 } \\
\text { German Landrace }^{\text {b }}\end{array}$ & $\begin{array}{l}\text { Gao et al. (15) } \\
\text { Ando et al. (34) } \\
\text { Reyes et al. (38) } \\
\text { Essler et al. (31) } \\
\text { Ho et al. (21) } \\
\text { Gimsa et al. (32) }\end{array}$ & Hp-0.24 & $\begin{array}{l}\text { Landrace } \times \text { Yorkshire } \\
\text { Big pigb }^{b} \\
\text { Pietrain }^{b} \\
\text { AGH, Y } \times \text { L, Yo }\end{array}$ & $\begin{array}{l}\text { Le et al. (26) } \\
\text { Ho et al. (17) } \\
\text { Essler et al. (31) } \\
\text { Le et al. (30) }\end{array}$ \\
\hline
\end{tabular}


TABLE 4 | Continued

\begin{tabular}{llllll}
\hline $\begin{array}{l}\text { SLA class I } \\
\text { haplotype }\end{array}$ & Breed $^{\text {a }}$ & Reference & $\begin{array}{l}\text { SLA class II } \\
\text { haplotype }\end{array}$ & Breed $^{\text {a }}$ & Reference \\
\hline Hp-58.0 & PT-K75 & Ho et al. (21) & Hp-0.27 & $\begin{array}{l}\text { Landrace } \times \text { Yorkshire } \\
\text { Guizhou }\end{array}$ & $\begin{array}{l}\text { Le et al. (26) } \\
\text { Liu et al. (39) } \\
\text { Ho et al. (17) } \\
\text { Le et al. (30) }\end{array}$ \\
\hline Hp-62.0 & & & Du, Ld, Y $\times$ L & \\
& Landrace & Tanaka-Matsuda et al. (20) & & \\
& Danish pigs ${ }^{\text {b }}$ & Pedersen et al. (19) & & \\
\hline Hp-64.0 & ESK-4 & Gimsa et al. (32) & & \\
& Pietrain & Ho et al. (21) & Essler et al. (31) & & \\
\hline
\end{tabular}

${ }^{a}$ Breed in which the haplotype has been reported.

bow-resolution SLA haplotype.

cHp-4c.0 differs from Hp-4a.O at the SLA-6 locus.

A

Sire \#3241

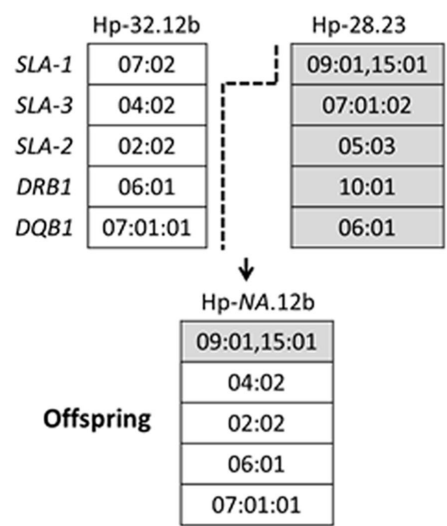

B

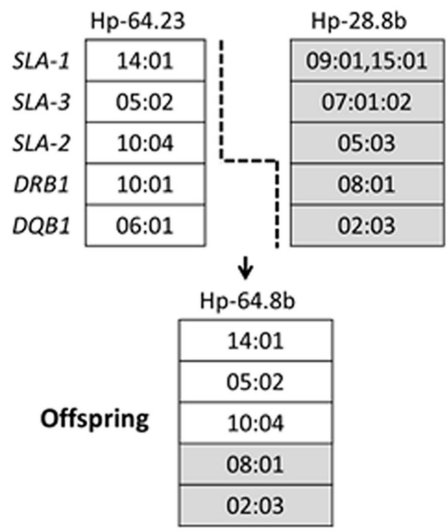

Sire \#5075

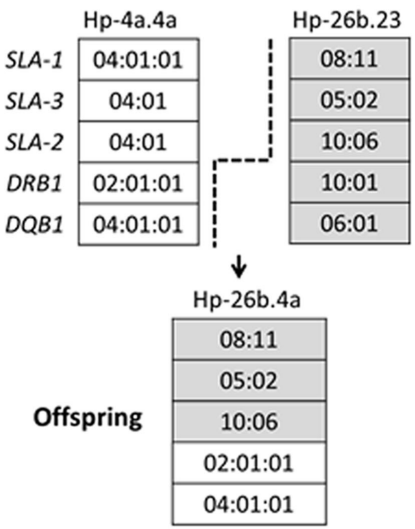

FIGURE 2 | Schematic diagram of swine leukocyte antigen (SLA) crossovers identified in Canadian specific pathogen-free Yorkshire and Landrace pigs. Five loci (SLA-1, SLA-3, SLA-2, DRB1, and DQB1) of the SLA complex are shown. Broken lines indicate probable positions where the crossover occurred. Panel (A) indicates one crossover within the class I region; panel (B) indicates two crossovers between class I and class II regions. NA, official designation of crossover class I haplotypes not assigned by the International Society for Animal Genetics SLA Nomenclature Committee.

virally derived peptides and made it possible to explore the nature of the SLA proteins and the roles they play in establishing adaptive immunity. It could also lead to accelerated development of peptide vaccines with increased efficacy due to optimal activation of cell-mediated immune responses with minimal adverse events. Moreover, the peptide motifs of MHC molecules can determine the resistance and susceptibility to some important animal pathogen, for example, for the dominantly expressed chicken MHC class I molecule (42). In this study, we confirmed the existence of four supertypes to analyze the specificities of 19 SLA class I molecules. However, the analysis also clearly revealed that not all class I molecules fitted equally well into a supertype classification scheme, and that each supertype consisted of class I molecules with highly divergent specificities. It demonstrate that common SLA class I proteins have high levels of functional diversity. The binding specificities represented by the sequence logos indicated that some different alleles (e.g., $S L A-3^{\star} 01: 01, S L A-3^{\star} 04: 01, S L A$ $3^{\star} 04: 02$, and $\left.S L A-3^{\star} 07: 01\right)$ appeared to be similar in terms of function and were classified in a single cluster using functional clustering. This indicated a somewhat shared functionality among the SLA class I proteins $S L A-3^{\star} 01: 01, S L A-3^{\star} 04: 01, S L A-$ $3^{\star} 04: 02$, and $S L A-3^{\star} 07: 01$ compared with other proteins (e.g., $S L A-1^{\star} 01: 01$ and $\left.S L A-2^{\star} 05: 02\right)$, and distinct from the others. It suggests that clustering analysis could be as a guide to help us understanding immunological phenotypic similarities between pig breeds using information about SLA types, especially for some pigs heterozygous at SLA class I loci. It could also provide information on where a specific allele (maybe present at a high frequency in a particular cohort) fits into the specificity space covered by the common MHC molecules. Furthermore, clustering analysis revealed functional differences among some SLA class I proteins, which suggests that we can produce these molecules to broaden the repertoire and achieve a higher chance of matching animals in terms of SLA expression in future peptide-epitope studies. The results of the current study thus demonstrate that the MHC clustering method can be used to identify specific MHC 


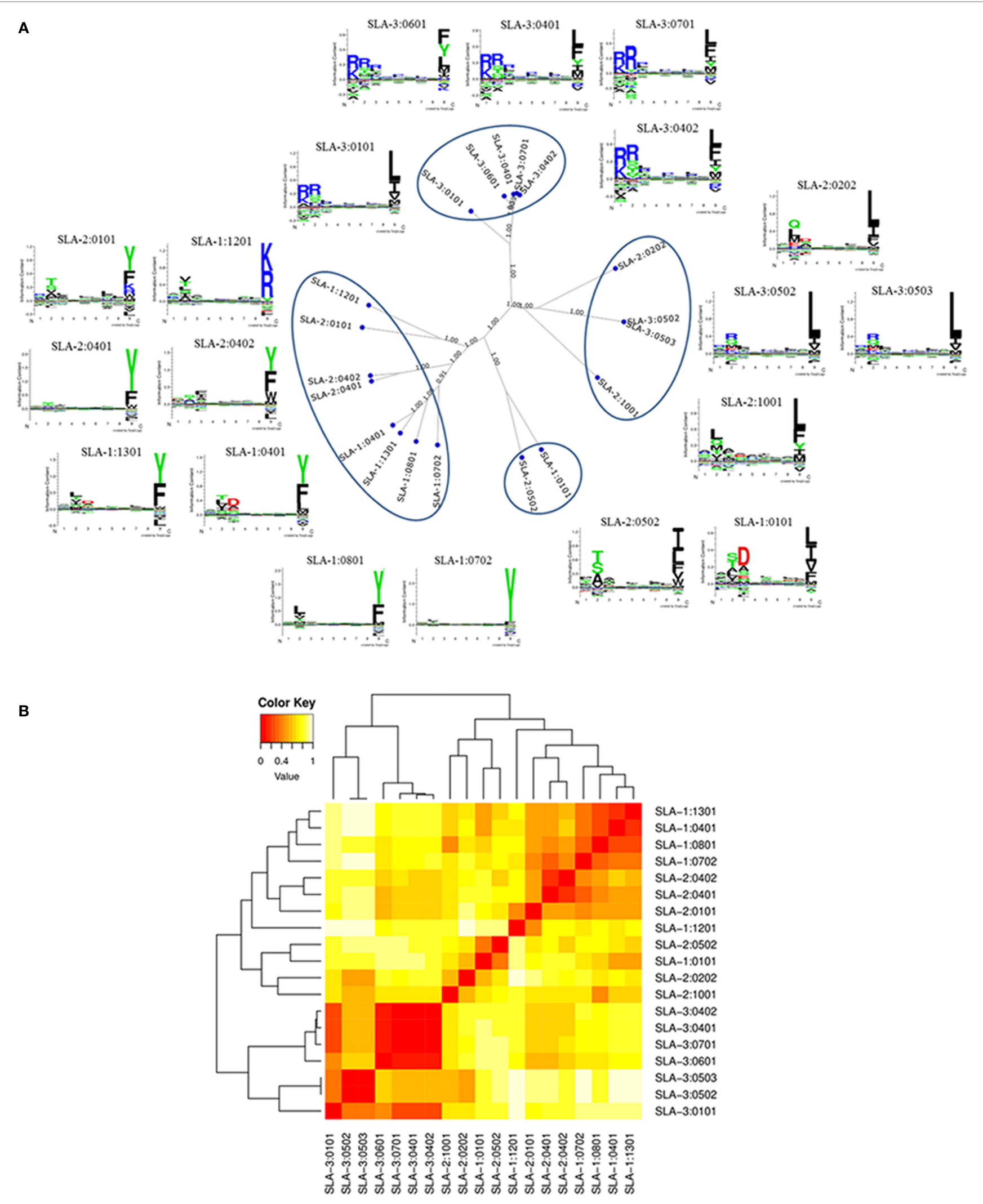

FIGURE 3 | Functional clustering of 19 identified frequent swine leukocyte antigen (SLA) class I alleles in Canadian specific pathogen-free Yorkshire and Landrace pigs using $\mathbf{M H C}$ cluster. Panel (A) shows a tree representation of the clustering; panel (B) shows a heat map representation. The tree was visualized using the advanced tree-viewer in MHCcluster. Sequence logos of the predicted binding specificity are included for each class I allele. 
proteins with the most diverse and broad coverage of the overall peptide-binding repertoire and chance for cytotoxic lymphocyte recognition.

In conclusion, we molecularly defined 17 class I haplotypes and 11 class II haplotypes in Canadian SPF Yorkshire and Landrace pigs using SBT and PCR-SSP methods. The official ISAG haplotype designations were assigned by the SLA Nomenclature Committee. These pig breeds with known SLA backgrounds will be valuable experimental animals for animal health and biomedical research, including swine immune responses and transplantation studies. We also have analyzed the functional diversities of 19 identified frequent SLA class I molecules and confirmed the existence of four supertypes using the MHCcluster method. This information is important for investigating immunological phenotypic differences, screening potential T-cell epitopes, and studying T-cell immune responses to specific epitopes of certain endemic pathogens.

\section{AUTHOR CONTRIBUTIONS}

CG and HC designed the experiments, analyzed the data, and wrote the paper. CG, JQ, and XJ performed the experiments. CL and XL collected samples.

\section{REFERENCES}

1. Renard C, Hart E, Sehra H, Beasley H, Coggill P, Howe K, et al. The genomic sequence and analysis of the swine major histocompatibility complex. Genomics (2006) 88:96-110. doi:10.1016/j.ygeno.2006.01.004

2. Neefjes J, Jongsma ML, Paul P, Bakke O. Towards a systems understanding of MHC class I and MHC class II antigen presentation. Nat Rev Immunol (2011) 11:823-36. doi:10.1038/nri3084

3. Lunney JK, Ho CS, Wysocki M, Smith DM. Molecular genetics of the swine major histocompatibility complex, the SLA complex. Dev Comp Immunol (2009) 33:362-74. doi:10.1016/j.dci.2008.07.002

4. Gao F, Fang Q, Li Y, Li X, Hao H, Xia C. Reconstruction of a swine SLA-I protein complex and determination of binding nonameric peptides derived from the foot-and-mouth disease virus. Vet Immunol Immunopathol (2006) 113:328-38. doi:10.1016/j.vetimm.2006.06.002

5. Oleksiewicz M, Kristensen B, Ladekjaer-Mikkelsen AS, Nielsen J. Development of a rapid in vitro protein refolding assay which discriminates between peptide-bound and peptide-free forms of recombinant porcine major histocompatibility class I complex (SLA-I). Vet Immunol Immunopathol (2002) 86:55-77. doi:10.1016/S0165-2427(02)00015-6

6. Zhang N, Qi J, Feng S, Gao F, Liu J, Pan X, et al. Crystal structure of swine major histocompatibility complex class I SLA-1*0401 and identification of 2009 pandemic swine-origin influenza A H1N1 virus cytotoxic T lymphocyte epitope peptides. JVirol (2011) 85:11709-24. doi:10.1128/JVI. 05040-11

7. Wang Y, Zhou Y, Li G, Zhang S, Jiang Y, Xu A, et al. Identification of immunodominant $\mathrm{T}$-cell epitopes in membrane protein of highly pathogenic porcine reproductive and respiratory syndrome virus. Virus Res (2011) 158:108-15. doi:10.1016/j.virusres.2011.03.018

8. Pedersen LE, Harndahl M, Rasmussen M, Lamberth K, Golde WT, Lund O, et al. Porcine major histocompatibility complex (MHC) class I molecules and analysis of their peptide-binding specificities. Immunogenetics (2011) 63:821-34. doi:10.1007/s00251-011-0555-3

9. Liao Y, Lin H, Lin C, Chung W. Identification of cytotoxic T lymphocyte epitopes on swine viruses: multi-epitope design for universal $\mathrm{T}$ cell vaccine. PLoS One (2013) 8:e84443. doi:10.1371/journal.pone.0084443

10. Gerner W, Kaser T, Saalmuller A. Porcine T lymphocytes and NK cells - an update. Dev Comp Immunol (2009) 33:310-20. doi:10.1016/j.dci.2008.06.003

\section{ACKNOWLEDGMENTS}

The authors wish to thank Dr. Chak-Sum Ho (Chair, ISAG SLA Nomenclature Committee; University of Michigan) for assigning the official SLA allele and haplotype designations. This research was supported by the National Natural Science Foundation of China (Grant No. 31502039).

\section{SUPPLEMENTARY MATERIAL}

The Supplementary Material for this article can be found online at http://journal.frontiersin.org/article/10.3389/fimmu. 2017.00282/full\#supplementary-material.

TABLE S1 | The pedigree of Canadian specific pathogen-free (SPF) Yorkshire and Landrace pigs with their respective check numbers assigned by Harbin Veterinary Research Institute.

TABLE S2 | Specificities of sequence-specific PCR primers for rapid swine leukocyte antigen (SLA) typing of Canadian specific pathogen-free (SPF) Yorkshire and Landrace pigs.

DATA SHEET 1 | The alignments of the nucleotide sequences including the complete coding sequences of 61 alleles identified in Canadian specific pathogen-free Yorkshire and Landrace pigs at five swine leukocyte antigen (SLA) loci.

11. Pedersen LE, Rasmussen M, Harndahl M, Nielsen M, Buus S, Jungersen G. A combined prediction strategy increases identification of peptides bound with high affinity and stability to porcine MHC class I molecules SLA$1 * 04: 01$, SLA- $2^{*} 04: 01$, and SLA- $3^{*} 04: 01$. Immunogenetics (2016) 68:157-65. doi:10.1007/s00251-015-0883-9

12. Gutierrez AH, Loving C, Moise L, Terry FE, Brockmeier SL, Hughes HR, et al. In vivo validation of predicted and conserved $\mathrm{T}$ cell epitopes in a swine influenza model. PLoS One (2016) 11:e0159237. doi:10.1371/journal. pone.0159237

13. Thomsen M, Lundegaard C, Buus S, Lund O, Nielsen M. MHCcluster, a method for functional clustering of MHC molecules. Immunogenetics (2013) 65:655-65. doi:10.1007/s00251-013-0714-9

14. Ho CS, Rochelle ES, Martens GW, Schook LB, Smith DM. Characterization of swine leukocyte antigen polymorphism by sequence-based and PCR-SSP methods in Meishan pigs. Immunogenetics (2006) 58:873-82. doi:10.1007/ s00251-006-0145-y

15. Gao C, Jiang Q, Guo D, Liu J, Han L, Qu L. Characterization of swine leukocyte antigen (SLA) polymorphism by sequence-based and PCR-SSP methods in Chinese Bama miniature pigs. Dev Comp Immunol (2014) 45:87-96. doi:10.1016/j.dci.2014.02.006

16. Ho CS, Lunney J, Franzo-Romain M, Martens G, Lee YJ, Lee JH, et al. Molecular characterization of swine leucocyte antigen class I genes in outbred pig populations. Anim Genet (2009) 40:468-78. doi:10.1111/j.1365-2052. 2009.01860.x

17. Ho CS, Lunney J, Lee JH, Franzo-Romain M, Martens G, Rowland $\mathrm{R}$, et al. Molecular characterization of swine leucocyte antigen class II genes in outbred pig populations. Anim Genet (2010) 41:428-32. doi:10.1111/j.1365-2052.2010.02019.x

18. Lee Y, Cho K, Kim M, Smith D, Ho C, Jung K, et al. Sequence-based characterization of the eight SLA loci in Korean native pigs. Int J Immunogenet (2008) 35:333-4. doi:10.1111/j.1744-313X.2008.00775.x

19. Pedersen LE, Jungersen G, Sorensen MR, Ho C-S, Vadekaer DF. Swine leukocyte antigen (SLA) class I allele typing of Danish swine herds and identification of commonly occurring haplotypes using sequence specific low and high resolution primers. Vet Immunol Immunopathol (2014) 162:108-16. doi:10.1016/j.vetimm.2014.10.007

20. Tanaka-Matsuda M, Ando A, Rogel-Gaillard C, Chardon P, Uenishi H. Difference in number of loci of swine leukocyte antigen classical class 
I genes among haplotypes. Genomics (2009) 93:261-73. doi:10.1016/ j.ygeno.2008.10.004

21. HoC, Franzo-Romain M,LeeY,LeeJ,Smith D. Sequence-based characterization of swine leucocyte antigen alleles in commercially available porcine cell lines. Int J Immunogenet (2009) 36:231-4. doi:10.1111/j.1744-313X.2009.00853.x

22. Smith D, Lunney J, Ho CS, Martens G, Ando A, Lee JH, et al. Nomenclature for factors of the swine leukocyte antigen class II system, 2005. Tissue Antigens (2005) 66:623-39. doi:10.1111/j.1399-0039.2005.00492.x

23. Smith D, Lunney J, Martens G, Ando A, Lee JH, Ho CS, et al. Nomenclature for factors of the SLA class-I system, 2004. Tissue Antigens (2005) 65:136-49. doi:10.1111/j.1399-0039.2005.00337.x

24. Ho CS, Lunney J, Ando A, Rogel-Gaillard C, Lee JH, Schook L, et al. Nomenclature for factors of the SLA system, update 2008. Tissue Antigens (2009) 73:307-15. doi:10.1111/j.1399-0039.2009.01213.x

25. Renard C, Vaiman M, Chiannilkulchai N, Cattolico L, Robert C, Chardon P. Sequence of the pig major histocompatibility region containing the classical class I genes. Immunogenetics (2001) 53:490-500. doi:10.1007/ s002510100348

26. Le M, Choi H, Choi MK, Cho H, Kim JH, Seo HG, et al. Development of a simultaneous high resolution typing method for three SLA class II genes, SLADQA, SLA-DQB1, and SLA-DRB1 and the analysis of SLA class II haplotypes. Gene (2015) 564:228-32. doi:10.1016/j.gene.2015.03.049

27. Ho CS, Martens GW, Amoss MS, Gomez-Raya L, Beattie CW, Smith DM. Swine leukocyte antigen (SLA) diversity in Sinclair and Hanford swine. Dev Comp Immunol (2010) 34:250-7. doi:10.1016/j.dci.2009.09.006

28. Smith DM, Martens GW, Ho CS, Asbury JM. DNA sequence based typing of swine leukocyte antigens in Yucatan miniature pigs. Xenotransplantation (2005) 12:481-8. doi:10.1111/j.1399-3089.2005.00252.x

29. Yeom SC, Park CG, Lee BC, Lee WJ. SLA typing using the PCR-SSP method and establishment of the SLA homozygote line in pedigreed SNU miniature pigs. Anim Sci J (2010) 81:158-64. doi:10.1111/j.1740-0929.2009. 00727.x

30. Le M, Choi H, Choi MK, Nguyen D, Kim JH, Seo H, et al. Comprehensive and high-resolution typing of swine leukocyte antigen DQA from genomic DNA and determination of 25 new SLA class II haplotypes. Tissue Antigens (2012) 80:528-35. doi:10.1111/tan.12017

31. Essler SE, Ertl W, Deutsch J, Ruetgen BC, Groiss S, Stadler M, et al. Molecular characterization of swine leukocyte antigen gene diversity in purebred Pietrain pigs. Anim Genet (2012) 44:202-5. doi:10.1111/j.1365-2052.2012. 02375.x

32. Gimsa U, Ho CS, Hammer SE. Preferred SLA class I/class II haplotype combinations in German Landrace pigs. Immunogenetics (2017) 69:39-47. doi:10.1007/s00251-016-0946-6

33. Choi NR, Seo DW, Choi KM, Ko NY, Kim JH, Kim HI, et al. Analysis of swine leukocyte antigen haplotypes in Yucatan miniature pigs used as biomedical model animal. Asian Australas JAnim Sci (2016) 29:321-6. doi:10.5713/ ajas. 15.0331

34. Ando A, Imaeda N, Ohshima S, Miyamoto A, Kaneko N, Takasu M, et al. Characterization of swine leukocyte antigen alleles and haplotypes on a novel miniature pig line, Microminipig. Anim Genet (2014) 45:791-8. doi:10.1111/ age.12199

35. Cho HO, Ho CS, Lee YJ, Cho IC, Lee SS, Ko MS, et al. Establishment of a resource population of SLA haplotype-defined Korean native pigs. Mol Cells (2010) 29:493-9. doi:10.1007/s10059-010-0061-8

36. Zeng R, Zeng YZ. Molecular cloning and characterization of SLA-DR genes in the 133-family of the Banna mini-pig inbred line. Anim Genet (2005) 36:267-9. doi:10.1111/j.1365-2052.2005.01277.x

37. Zeng R, Miao YW, Huo JL, Pan WR, Zeng YZ. Molecular cloning and characterization of SLA-DQ cDNA of the Banna mini-pig inbred line family 133. Acta Laboratorium Animalis Scientia Sinica (2005) 13:215-21. Chinese.

38. Reyes LM, Blosser RJ, Smith RF, Miner AC, Paris LL, Blankenship RL, et al. Characterization of swine leucocyte antigen alleles in a crossbred pig to be used in xenotransplant studies. Tissue Antigens (2014) 84:484-8. doi:10.1111/ $\tan .12430$

39. Liu Z, Xia J, Xin L, Wang Z, Qian L, Wu S, et al. Swine leukocyte antigen class II genes (SLA-DRA, SLA-DRB1, SLA-DQA, SLA-DQB1) polymorphism and genotyping in Guizhou minipigs. Genet Mol Res (2015) 14:15256-66. doi:10.4238/2015.November.30.1

40. Gleimer M, Parham P. Stress management: MHC class I and class I-like molecules as reporters of cellular stress. Immunity (2003) 19:469-77. doi:10.1016/ S1074-7613(03)00272-3

41. Fan S, Wu Y, Wang S, Wang Z, Jiang B, Liu Y, et al. Structural and biochemical analyses of swine major histocompatibility complex class I complexes and prediction of the epitope map of important influenza A virus strains. J Virol (2016) 90:6625-41. doi:10.1128/jvi.00119-16

42. Wallny HJ, Avila D, Hunt LG, Powell TJ, Riegert P, Salomonsen J, et al. Peptide motifs of the single dominantly expressed class I molecule explain the striking MHC-determined response to Rous sarcoma virus in chickens. Proc Natl Acad Sci U S A (2006) 103:1434-9. doi:10.1073/pnas.0507386103

Conflict of Interest Statement: The authors declare that the research was conducted in the absence of any commercial or financial relationships that could be construed as a potential conflict of interest.

Copyright $\odot 2017$ Gao, Quan, Jiang, Li, Lu and Chen. This is an open-access article distributed under the terms of the Creative Commons Attribution License (CC BY). The use, distribution or reproduction in other forums is permitted, provided the original author(s) or licensor are credited and that the original publication in this journal is cited, in accordance with accepted academic practice. No use, distribution or reproduction is permitted which does not comply with these terms. 